\title{
VALIDITAS BAHAN AJAR BERBASIS RISET PADA MATERI SISTEM REPRODUKSI SMA/MA
}

\author{
Yulia Maiher Tati, Ria Kasmeri, Febri Yanti \\ Program Studi Pendidikan Biologi STKIP PGRI Sumatera Barat \\ $\underline{\text { Yuliamaihertati10@gmail.com }}$
}

\begin{abstract}
This research is motivated by the limited material in printed books, the book is distributed to students one book for two people and distributed when the learning process is only in school, this makes the learning process very ineffective, for that students need additional teaching materials, especially reproductive system material at school. contraceptive method sub material in the family planning (KB) program. Research conducted in February 2020 aims to produce valid teaching materials for the reproductive system of SMA / MA. The method used in this research is the 4-D model method. Data analysis was carried out by descriptive method. The instrument used in this study was a validity test questionnaire, which was conducted by 3 expert validators, namely 2 lecturers and 1 teacher. The results obtained from the validity test showed a validity value of $86,9 \%$ with very valid criteria because it was in accordance with the content standards, basic competencies and core competencies that had been set.
\end{abstract}

\section{Keywords: Teaching Materials, Validity}

\section{PENDAHULUAN}

Bahan ajar ialah berbagai bentuk bahan yang dipakai guru pada aktivitas pembelajaran, bahan tersebut bisa tertulis maupun tidak tertulis (Sitohang, 2014). Prastowo (2011) menyampaikan bahwa pada kegiatan pembelajaran siswa dan guru memakai bahan ajar, ialah materi pelajaran yang disusun secara sistematis. Sedangkan menurut Januar (2017) bahan ajar ialah segala informasi, alat, maupun teks yang disusun secara sistematis, serta mempelihatkan bentuk utuh dari kompetensi yang akan dikuasai oleh siswa dalam proses pembelajaran.

Tujuan dari penyusunan bahan ajar adalah mendorong siswa untuk mempelajari, menyajikan bermacam bahan ajar dan dapat mencegah munculnya rasa bosan siswa, agar aktivitas pembelajaran menarik, dan memudahkan siswa saat proses pembelajaran. Manfaat bahan ajar oleh guru adalah membantu guru saat proses pembelajaran serta bisa menjadikan nilai tambahan pada saat kenaikan pangkat. Sedangkan manfaat bahan ajar bagi 
siswa ialah mempermudah siswa mempelajari setiap potensi yang harus dikuasainya, dan membuat proses belajar mengajar jadi lebih menarik (Prastowo, 2011).

Menurut Nurdyansyah (2015) bahan ajar berfungsi membantu guru dalam mengarah siswa tentang materi yang harus dikuasainya saat proses pembelajaran, sedangkan fungsi bahan ajar bagi siswa yaitu sebagai petunjuk dalam pemahan materi dan tambahan bahan ajar dalam proses pembelajaran.

Berdasarkan bentuk bahan ajar dibagi atas 4 yaitu audio, pandang, cetak, dan interaktif. Bahan ajar cetak (Pinted) merupakan bahan yang disajikan dengan kertas, bisa digunakan sebagai media penyampaian informasi. Misalnya lembar kerja siswa, modul, buku, dan, brosur. Bahan ajar audio ialah segala sistem yang memakai sinyal secara lansung dan bisa didengarkan banyak orang, misalnya seperti radio serta kaset, bahan pandang ialah sesuatu yang bisa disatukan berupa gambar bergerak secara sekuensial, seperti video danfilm, sedangkan bahan ajar interaktif ialah gabungan dari grafik, video, dan gambar yang bagi penggunanya diberi perlakuan guna mengendalikan suatu perintah (Prastowo, 2011).

Buku terdiri dari 4 macam, yaitu buku sumber, bacaan, buku pegangan, dan bahan ajar. Buku sumber ialah buku yang digunakan sebagai bahan rujukan analisis suatu ilmu tertentu, buku bacaan merupakan buku yang digunakan sebagai bahan bacaan saja, buku pegangan merupakan buku yang digunakan sebagai pegangan oleh guru saat pembelajaran, sedangkan bahan ajar adalah buku yang berisikan materi yang akan diajarkan (Prastowo, 2011).

Buku teks sebagai bahan ajar ada 2 jenis, yaitu buku utama dan buku pelengkap Buku utama merupakan buku yang dipakai sebagai buku pokok oleh guru dan siswa dalam pembelajaran, sedangkan buku pelengkap ialah buku yang digunakan sebagai pelengkap dari buku utama (Prastowo, 2011).

Didalam buku teks pelajaran tersebut menjelaskan tentang materi beserta uraiannya, yang bertujuan untuk membantu siswa dalam memahami materi yang akan dipelajari, salah satunya adalah materi sistem reproduksi. 
Materi sistem reproduksi adalah salah satu materi yang dipelajari di kelas XI SMA/MA yang menjelaskan tentang proses reproduksi yang terjadi pada makhluk hidup, materi tersebut dianggap sulit oleh siswa karena dalam materi tersebut terdapat tahap- tahap reproduksi yang susah dipahami oleh siswa dan menyebabkan siswa mengalami kendala dalam proses pembelajaran.

Berdasarkan uraian diatas maka disusunlah buku ajar untruk pembelajaran pada materi sistem reproduksi. Kemuadian buku tersebut dilakukan uji validitasnya melalui penilaian dosen dan guru.

Berdasarkan penelitian yang telah dilakukan oleh Sistyarini (2017) tentang Analisis Validitas terhadap Pengembangan Handout Berbasis Masalah pada Materi Pencemaran Lingkungan Kelas VII SMP/MTS didapatkan hasil bahwa handout dikembangkan dengan model pengembangan 3D adapatasi dari 4D melalui uji validasi dengan instrumen kembar penilaian mendapatkan nilai rata-rata $82,33 \%$ dengan kategori valid berdasarkan aspek kelayakan isi, , penyajian materi, serta bisa dipakai dalam pembelajaran di sekolah. Febriyanti dkk (2016) juga melakukan penelitian tentang Uji Validitas Lembar Kerja Mahasiswa (LKM) Berbasis Matery Learning Pada Mata Kuliah Genetika, didapatkan hasil bahwa Pengembangan Lembar Kerja Siswa yang dilakukan tersebut didapakan nilai validitas sebesar $88 \%$ dengan kriteria valid.

Dari latar belakang diatas maka rumusan masalah penelitian ini ialah bagaimana validitas bahan ajar pada materi sistem reproduksi. Berdasarkan rumusan masalah tersebut, maka tujuan penelitian ini ialah untuk mengetahui validitas bahan ajar ajar pada materi sistem reproduksi.

\section{METODE PENELITIAN}

Jenis penelitian berupa penelitian pengembangan. Produk yang dihasilkan berupa buku ajar pada materi sistem reproduksi pada sub materi metode kontrasepsi dalam program Keluarga Berencana (KB) kelas XI. Buku ajar dikembangkan dengan model 4-D yang 
terdiri dari 4 tahap, yaitu define, design dan develop (Trianto, 2007).

Instrumen yang dipakai pada penelitian ini berupa angket lembar penilaian validasi dengan teknik pengumpulan data yang akan dinilai oleh Dosen dan Guru. Uji validitas dilakukan dengan 4 aspek yaitu aspek kelayakan isi, penyajian materi, kebahasaan serta kegrafikan yang dimodifikasi dari Nesti, 2018.

\section{HASIL DAN PEMBAHASAN}

Bahanajar dikembangkan sesuai dengan hasil observasi yang dilakukan, dimana dalam proses pembelajaran siswa membutuhkan tambahan media pembelajaran berupa buku ajar untuk menunjang kelancaran dalam proses pembelajaran. Pembuatan bahan ajar dilatar belakangi terbatasnya jumlah buku yang disediakan pihak sekolah.

Faktor lain yang mendukung perlunya pengembangan bahan ajar ini yaitu rendahnya minat baca dan pemahaman siswa terhadap materi sistem reproduksi. Data tersebut menunjukan bahwa bahan ajar yang dibuat dapat meningkatkan minat baca dan pengetahuan siswa terhadap materi sistem reproduksi.

Menurut Prastowo (2011) dalam penyusunan bahan ajar harus menggunakan bahasa yang jelas, kalimat yang jelas dan singkat, serta dapat dibaca dengan mudah. Sitepu (2012) juga menjelaskan bahwa dalam penyusunan buku teks pelajaran hendaknya menggunakan tata bahasa yang baku dari sumber- sumber resmi seperti Ejaan Bahasa Indonesia (EBI) serta istilah dalam bahasa indonesia. Romansyah (2016) juga menjelaskan bahwa dalam penyusunan bahan ajar harus mempertimbangkan kriteria keterbacaan pada bahan ajar.

Menurut Majid (2011) dalam penyususnan suatu bahan ajar harus ada unsur seperti kompetensi yang ingin dicapai, petunjuk kerja, latihan dan imformasi pendukung. Supaya cocok dengan standar tersebut maka bahan ajar yang dibuat sebelum digunakan harus divalidasi oleh dosen dan guru, kemudian buku tersebut diperbaiki dan dibawa kembali kepada dosen dan guru tersebut. 
Validitas bahan ajar dilihat dari 3 Berikut hasil validasi bahan ajar dari aspek yaitu, aspek kelayakan isi, validator:

kebahasaan, penyajian, dan kegrafikan.

Tabel 1. Hasil Validitas Buku Ajar oleh Validator

\begin{tabular}{cccccccc}
\hline Aspek & \multicolumn{3}{c}{ Validator } & Skor & Skor & Nilai & Kriteria \\
\cline { 2 - 7 } & I & II & III & diperoleh & tertinggi & validitas & \\
\hline Kelayakan Isi & 32 & 29 & 29 & 90 & 105 & $85,7 \%$ & Sangat valid \\
Kebahasaan & 24 & 20 & 25 & 69 & 75 & $92 \%$ & Sangat valid \\
Penyajian & 32 & 30 & 30 & 92 & 105 & $87,6 \%$ & Sangat valid \\
Kegrafikan & 24 & 21 & 25 & 70 & 75 & $93,3 \%$ & Sangat valid \\
& \multicolumn{3}{c}{ Total } & & & $358,6 \%$ & \\
& \multicolumn{3}{c}{ Rata-rata } & & & $89,6 \%$ & Sangat valid \\
\hline
\end{tabular}

Keterangan : (I) Rina Widiana, M. Si, (II) Vivi Fitriani, M. Pd, (III) Ayani, M. Pd.

Berdasarkan tabel 1 dapat dilihat Akbar (2013) bahwa bahan ajar yang dari apek kelayakan isi, bahan ajar baik mempunyai kecocokan antara materi sistem reproduksi ini menunjukan kompetensi yang harus dipahami dengan nilai validitas $85,7 \%$ dengan kriteria cakupan isi, kedalaman pembahasan, dan sangat valid. Berdasarkan kriteria yang kompetensi siswa. Sedangkan menurut telah didapatkan dari dosen dan guru Rozalia (2018) suatu bahan ajar bidang studi biologi, maka bahan ajar dikatakan layak digunakan apabila bahan yang dikembangkan telah cocok dengan ajar tersebut sesuai dengan Standar tuntutan kurikulum yang berlaku dan Kompetensi, Kompetensi Dasar, cocok dengan Kompetensi Inti, indikator serta tujuan pembelajaran yang Kompetensi Dasar yang ingin dicapai, akan dicapai. Nerita dkk (2018) juga materi yang disajikan sudah menunjang mengatakan bahwa suatu bahan ajar dalam mencapai tujuan pembelajaran, dikatakan valid apabila telah sesuai dan sesuai dengan sesuai dengan dengan kurikulum, capaian kebutuhan siswa, dapat menambah pembelajaran, bahan kajian dan wawasan pengetahuan siswa. Menurut 
kebenaran substansi materi ajar dikatakan valid apabila bahan ajar pembelajaran. tersebut memuat struktur bahasa yang

Berdasarkan aspek kebahasaan bahan ajar materi sistem reproduksi ini menunjukan nilai validitas $92 \%$ dengan kriteria sangat valid. Kriteria ini diperoleh karena bahan ajar ini jika dilihat dari aspek kebahasaan menunjukan bentuk serta ukuran huruf yang mudah dibaca dan dipahami, menyampaikan informasi yang jelas serta menggunakan bahasa dengan kaidah yang benar. Menurut Sitepu (2012)menyatakan bahwa dalam menggunakan bahasa, penulisan buku teks pelajaran hendaknya menggunakan tata bahasa yang baku dari sumbersumber resmi seperti Ejaan Bahasa Indonesia (EBI) Serta istilah dalam bahasa Indonesia menjelaskan bahwa dalam penyusunan bahan ajar harus memakai bahasa yang baik serta mudah dipahami, penyajiannya menarik dan dilengkapi gambar beserta keterangan yang lengkap, isi buku menggambarkan sesuatu yang cocok dengan pendapat penulisnya, serta disusun berdasarkan kurikulum yang berlaku. Aisyah (2017) juga menjelaskan bahwa suatu bahan jelas serta mudah dibacadan dipahami.

Dilihat dari aspek penyajian, bahan ajar materi sistem reproduksi ini menunjukkan nilai validitas $87,6 \%$ dengan kriteria sangat valid. Kriteria tersebut didapat karena bahan ajar ini sudah menyediakan materi yang sesuai dengan kompetensi yang harus dicapai, dan bahan ajar ini menyajikan materi berdasarkan penelitian yang dilakukan. Menurut Majid (2011) bahwa dalam penyusunan bahan ajar harus ada unsur penyusunnya seperti kompetensi yang ingin dicapai, informasi pendukung, latihan, petunjuk kerja agar mempermudah siswa saat proses pembelajaran. Menurut Rozalia (2018) bahan ajar dikatakan valid apabila dikembangkan berdasarkan dua unsur yaitu judul dan informasi pendukung. Judul mencakup hal yang berkaitan dengan identitas, sedangkan informasi pendukung berhubungan dengan kemauan dan keterampilan penulis dalam menyajikan materi. Sedangkan Menurut Sitepu (2012) komponen yang 
terdapat dalam bahan ajar yaitu judul, daftar isi, prakarta, petunjuk penggunaan, pendahuluan, materi, latihan, serta daftar pustaka.

Berdasarkan aspek kegrafikan, bahan ajar materi sistem reproduksi ini menunjukkan nilai validitas 93,3 \% dengan kriteria sangat valid. Bahan ajar ini sudah memenuhi aspek kegrafikan yaitu dari segi bentuk dan ukuran huruf dalam bahan ajar menarik, tata letak isi dan tampilan pada bahan ajar ini sudah menarik. Hal ini juga diungkapkan oleh Prastowo (2011) bahwa penggunaan grafis dan gambar dalam suatu bahan ajar mampu untuk memotivasi siswa dalam pembelajaran .Monica (2011) mengatakan warna merupakan pendukung dalam desain yang harus diperhatikan. Sebuah rancangan dikatakan menarik jika ditanggapi oleh audience dan emosi mereka ikut tergerak serta pesan yang ada pada desain tersampaikan ke otak mereka.

Berdasarkan hasil analisis validasi bahan ajar materi sistem reproduksi oleh validator secara keseluruhan bahan ajar bahan ajar ini sudah sangat valid dengan nilai validitas $91,62 \%$. Hal ini berarti bahan ajar telah memenuhi keempat aspek yang dinilai dalam uji validitas, yaitu aspek kelayakan isi, penyajian, kebahasaan serta kegrafikan. Menurut Romansyah (2016) suatu bahan ajar dikatakan valid apabila bahan ajar tersebut telah memenuhi 2 kriteria, yaitu kriteria umum dan kriteria khusus. Kriteria umum adalah kriteria yang berisi prinsip, langkah serta penyajian bahan ajar. Sedangkan kriteria khusus adalah kriteria yang mencakup kriteria keilmuan, ilmu pendidikan dan keguruan, serta kriteria keterbacaan bahan ajar. Suswina (2011) juga mengatakan bahwa suatu bahan ajar dikatakan valid apabila bahan ajar tersebut sesuai dengan materi yang disajikan, mampu memotivasi siswa untuk membaca, dan menimbulkan rasa ingin tau siswa untuk melakukan eksplorasi lebih lanjut tentang materi yang dipelajari.

Berdasarkan hasil validasi yang dilakukan didapatkan bahwa bahan ajar materi sistem reproduksi yang dibuat sangat valid, namun harus dilakukan lagi revisi berdasarkan saran validator yang terdapat pada tabel 2 berikut ini: 
Tabel 2. Saran Validator Untuk Perbaikan Bahan Ajar

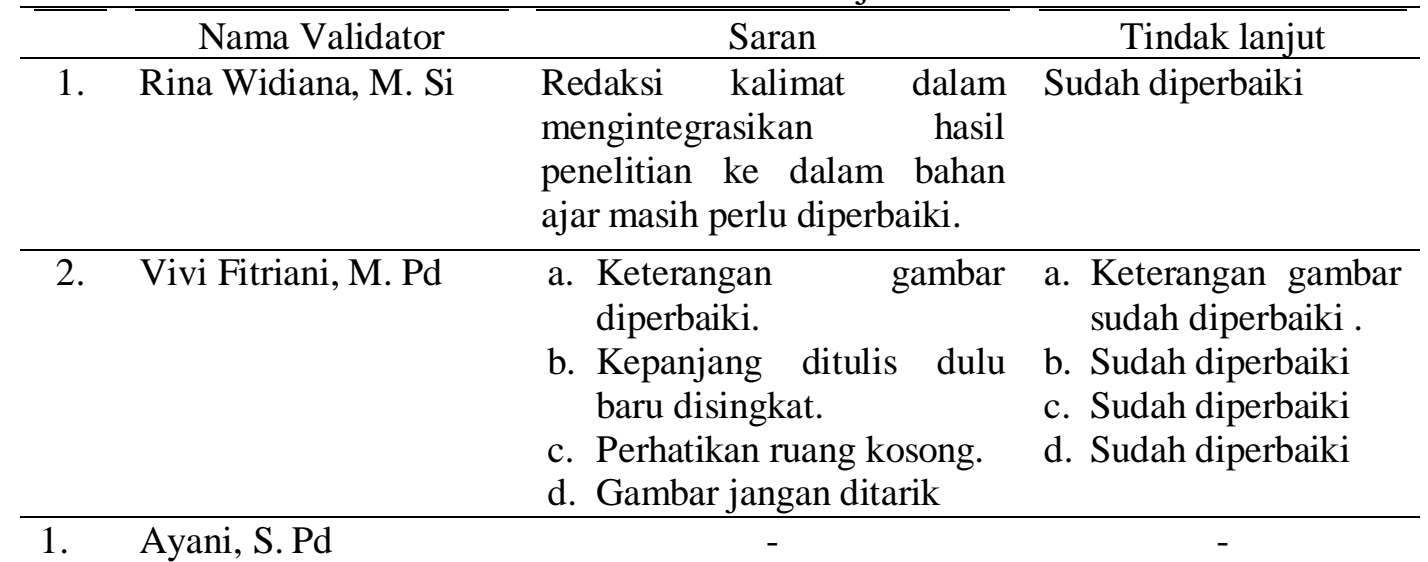

Sumber: Dokementasi Pribadi

Setelah dilakukan revisi berdasarkan saran yang diberikan oleh validator, maka bahan ajar kembali dinilai serta divalidasi oleh validator. Setelah divalidasi dan diperbaiki maka buku ajar yang dihasilkan bisa digunakan sebagai bahan ajar pada materi sistem reproduksi. Pernyataan valid oleh validator ini didukung dengan adanyahasil pengolahan dan analisis data yang dilakukan.

\section{KESIMPULAN}

Berdasarkan penilaian yang telah dilakukan, maka dapat disimpulkan bahwa bahan ajar yang dihasilkan sangat valid serta dapat dipakai sebagai sumber bacaan pada materi sistem reproduksi kelas XI SMA/MA.

\section{DAFTAR PUSTAKA}

Aisyah, D. W. (2017). Pengembangan Bahan Ajar Berbasis Literasi Bercirikan Quantum Teaching Untuk Mengoptimalkan Pembelajaran. Pendidikan, 2(5), 667-675.

Akbar, S. (2013). Instrumen Perangkat Pembelajaran. PT Remaja Rosdakarya.

Febriyanti, Diana, S., \& S, R. R. P. M. (2016). Uji Validitas Lembar Kerja Mahasiswa (LKM) Berbasis Mastery Laerning Pada Mata Kuliah Genetika. Biologi Education, 5(1), 50-54.

Januar, H. (2017). Pengembangan Bahan Ajar Untuk Menumbuhkan Nilai Karakter Peduli Lingkungan Pada Siswa Kelas IV Sekolah Dasar. Profesi Pendidikan Dasar, 4(1), 62-74.

Majid. (2011). Perencanaan 
Pembelajaran. PT Remaja Rosdakarya.

Monica, L. (2011). Efek Warna dalam Dunia Desain dan Periklanan. Humaniora, 2(2), 1084-1096.

Nerita, S., Hartati, Y. S., \& Afza, A. (2018). Validitas Handout Berbasis Penemuan Terbimbing Pada Perkuliahan Evaluasi Proses Dan Hasil Belajar Biologi. Jurnal Penelitian Pendidikan IPA, 4(2).

Nurdyansyah. (2015). Pengembangan Bahan Ajar Modul Ilmu Pengetahuan Alambagi Siswa Kelas Iv Sekolah Dasar. Pendekatan Saintifik, 20.

Prastowo, A. (2011). Panduan Kreatif Membuat Bahan Ajar Inovatif. Diva Press.

Romansyah, K. (2016). Pedoman Pemilihan dan Penyajian Bahan Ajar Mata Pelajaran Bahasa dan Sastra Indonesia. Jurnal Logika, XVII(2), 59-66.

Rozalia, A. (2018). Pengembangan Handout Biologi Materi X. Jurnal Pendidikan Dan Pembelajaran Biologi, 2(2), 44-51.

Sistyarini, D. E. (2017). Analisis Validitas terhadap Pengembangan Handout Berbasis Masalah pada Materi Pencemaran Lingkungan Kelas VII SMP / MTS. 14(2014), 581-584.

Sitepu. (2012). Penulisan Buku Teks
Pelajaran. PT Remaja Rosdakarya.

Sitohang, R. (2014). Mengembangkan Bahan Ajar Dalam Pembelajaran Ilmu Pengetahuan Sosial (IPS) Di SD. 23.

Suswina, M. (2011). Hasil Validitas Pengembangan Bahan Ajar Bergambar Disertai Peta Konsep Untuk Pembelajaran Biologi SMA Semester 1 Kelas XI. Ta'dib, 14(1)..

Trianto. (2007). Mendesaian Model Pembelajaran Inovatif, Prograsif, Dan Kontekstual. Kencana Pramedia Group. 